\author{
Journal of Asian Business Strategy \\ $\operatorname{ISSN}(e): 2225-4226$ \\ $\operatorname{ISSN}(p): 2309-8295$ \\ DOI: 10.18488/journal.1006/2017.7.2/1006.2.66.77 \\ Vol. 7, No. 2, 66-77. \\ (C) 2017 AESS Publications. All Rights Reserved. \\ URL: www.aessweb.com \\ check for \\ updates
}

\title{
TREND AND POSITIONING OF GLOBAL TOP ONE HUNDRED BRANDS
}

\author{
Rain Chen ${ }^{1+}$ \\ Jo-Han Chang ${ }^{2}$ \\ Hung-Yuan Chen ${ }^{3}$
}

\author{
${ }^{1,3}$ Department of Visual Communication Design, Southern Taiwan University of Science \\ and Technology, Taiwan, R.O.C. \\ Email:ocean@stust.edu.tw \\ ${ }^{2}$ Department of Industrial Design, National Taipei University of Technology, Taiwan, \\ R.O.C.
}

\section{Article History}

Received: 7 May 2018

Revised: 13 July 2018

Accepted: 2 August 2018

Published: 24 August 2018

\section{Keywords:}

Global brands

Trend

Positioning

Competitive stress

\begin{abstract}
This study applied 173 figurative marks from global top 100 brands from 2006 to 2015 as the objects. The brand distinctiveness test was implemented to 60 general consumers. The Multidimensional Scaling was applied in order to get the similarity of the eight majors industries from the participants. The researcher further established the Twodimensional Brand Positioning Map (BPM) in order to help the enterprises making brand strategy. The BPM may assist the managers observing the brand positioning of their own enterprises. From the developing trend of the brands of each year, the brand competitive stress of their own enterprises can be observed. The study found that: for the global top one hundred brands, they have excellent distinctiveness to the consumers. In the future, enterprises may apply this approach of analysis to establish their own BPM in order to recognize the trend and positioning of their own brands in the

corresponding industries.
\end{abstract}

Contribution/ Originality: Through the sample distribution of global top one hundred brands, it is expected to understand the developing trend and brand positioning of global brands, and it can become the reference to enterprises planning the brand image. The enterprises can apply this analysis to establish their own brand positioning map in the future in order to understand the trend and positioning of the own brands in the industry.

\section{INTRODUCTION}

From the view of design, it is obvious that the modality involved in design is diversified. This includes solid equipment or structure, virtual system and strategy. These modalities have certain overlapping and correlation with design. This implies that the complexity and diversification of the design subject.

The three major laws dealing with the intellectual property right are the Patent Act, the Trademark Act, and the Copyright Act. These three Acts form the basic protection scope of design. 
Therefore, they are also known as three major laws of intellectual property right. The three major laws of intellectual property right include the scope such as product design, visual communication design, architectural design, and media design. Among them, the Trademark Act is the intellectual property right that is closely related with brand competition.

Both patent right and trademark right belong to industrial property right while copyright belong to cultural property right. In general, the industrial property right has exclusive right. Therefore, the attribute of the right is relatively aggressive. The cultural property right only includes the Copyright and the attribute is relatively weak. When the design is the focus of protection, various design modalities (such as structure, device, strategy, and color) are practically under the protection of intellectual property right. The modalities protected by Patent Act include seven items: method, composition, device, shape, pattern, color, and interface (Patent Act, 2016). The modalities protected by Trademark Act include six items: text, figure, mark, color, voice, and three-dimensional shape (Trademark Act, 2016). The modalities protected by Copyright Act include 10 items: Oral and literary works, Musical works, Dramatic and choreographic works, Artistic works, Photographic works, Pictorial and graphical works, Audiovisual works, Sound recordings, Architectural works, and Computer programs (Copyright Act, 2016). This study focused on analysis of brand positioning, and the figurative trademark in Trademark Act was studied.

Chen and Chen proposed the protection scope of design (Chen and Chen, 2007) as shown in Figure 1. That study classified nature of right of patent, trademark, and copyright. Patent is mainly for protection of profit creation. Trademark is mainly for protection of trade order. Copyright is mainly for protection of culture creation. Among them, the Trademark Act is closely related to brand competition.

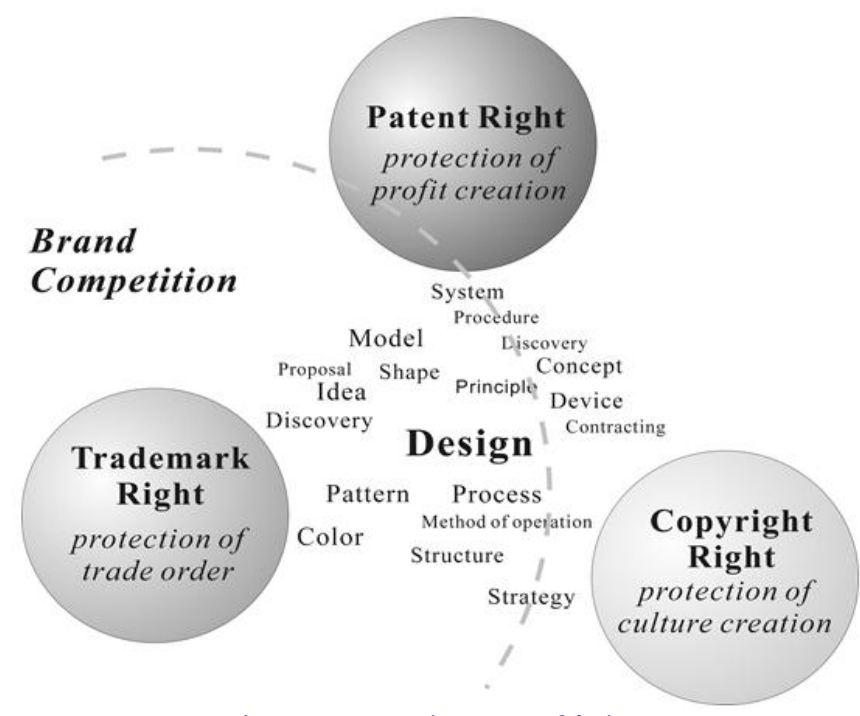

Figure-1. Protection scope of design.

Combing the brand with marketing becomes the key factor of the enterprises extending the business territory and developing towards the world. The relevant research found that there is positive correlation between brand positioning and profit of the enterprise. Most of the enterprises using the brands as competition oriented, have increased the profit almost one time (Johan and Frans, 2011). The power of brands depends on the impression of the consumers. If consumers have better impression to the brands, the satisfaction and royalty will be higher (Thiripurasundari and Natarajan, 2011). The brand image becomes the major factor driving the consumption of the consumers. In addition, the effect is more obvious for famous brands (Parker, 2009). Therefore, unscrupulous merchandisers always make similar trademarks confusing customers, who believe 
that they purchased certified products (Mealem et al., 2010). For the topic about trademark infringement, if another brand comes to their mind when they see a certain brand, this may cause trademark infringement even the consumers recognize the difference between the trademarks of the two brands (Arvidsson, 2006).

Some scholars had studied the brand positioning of the famous brands (Chen and Liang, 2012) and applied case study for brand positioning (Chen and Wang, 2015). Some other scholars had analyzed the brand positioning of various industries (Jeng and Yeh, 2016; Aarstad et al., 2015). Besides, relevant studies also showed that designers have lower difference threshold (Liu, 1995). This implies that designers are more sensitive to identify the tiny difference of the trademark. The essence of trademark is to avoid intentional plagiarism, which confuses consumers. Therefore, the participants of this study were mainly the general consumers. The result of the study had generality and commonality.

From the Brand Positioning Map (BPM) of the global top one hundred brands, this study applied visual approach showing the overall arrangement and positioning between the brands. It was expected breaking the trademark examination and concept restriction from individual case in the past. From the analysis of brand positioning of long-term brand competitors in the same industry, it was expected to introduce the developing trend of global top one hundred brands in recent 10 years (2006-2015), and established the Brand Positioning Map objectively. This Brand Positioning Map would be helpful to enterprises, designers, courts, and public to identify the two-dimensional trademarks more definitely. Enterprises can apply the Brand Positioning Map as the edge tool of brand competition. If the of enterprises apply brand innovation as the major measure of competition, it demands urgent attention to understand the global brand trend and positioning.

\section{METHOD}

\subsection{Subjects}

The test of this study involved 60 general consumers (the major observers of trademarks are general consumers). Among them, there were 21 male participants (35\%) and 39 female participants (65\%). The average age of participants was 37 . The average brand familiarity of eight major industries was 3.14 for the participants. The Likert Scale was applied for the measure (Lubiano et al., 2016). The scale was 1-5, for which 1 represented most unfamiliar and 5 represented most familiar. The result showed that the participants had middle level above of familiarity to the test samples.

\subsection{Samples}

The famous brand appraisal company will give the ranking of global brand value every year. The famous brands are always the counterfeit objects. In this study, the top one hundred twodimensional brands from the global one hundred brands BrandZ 2006-2015 (10 years of trademark samples) were selected as the study samples (BrandZ, 2016). There were 173 figurative trademarks involved (as shown in Figure 2). Due to the restriction of the capacity of publication, the study of relevant text trademarks will be written independently. 


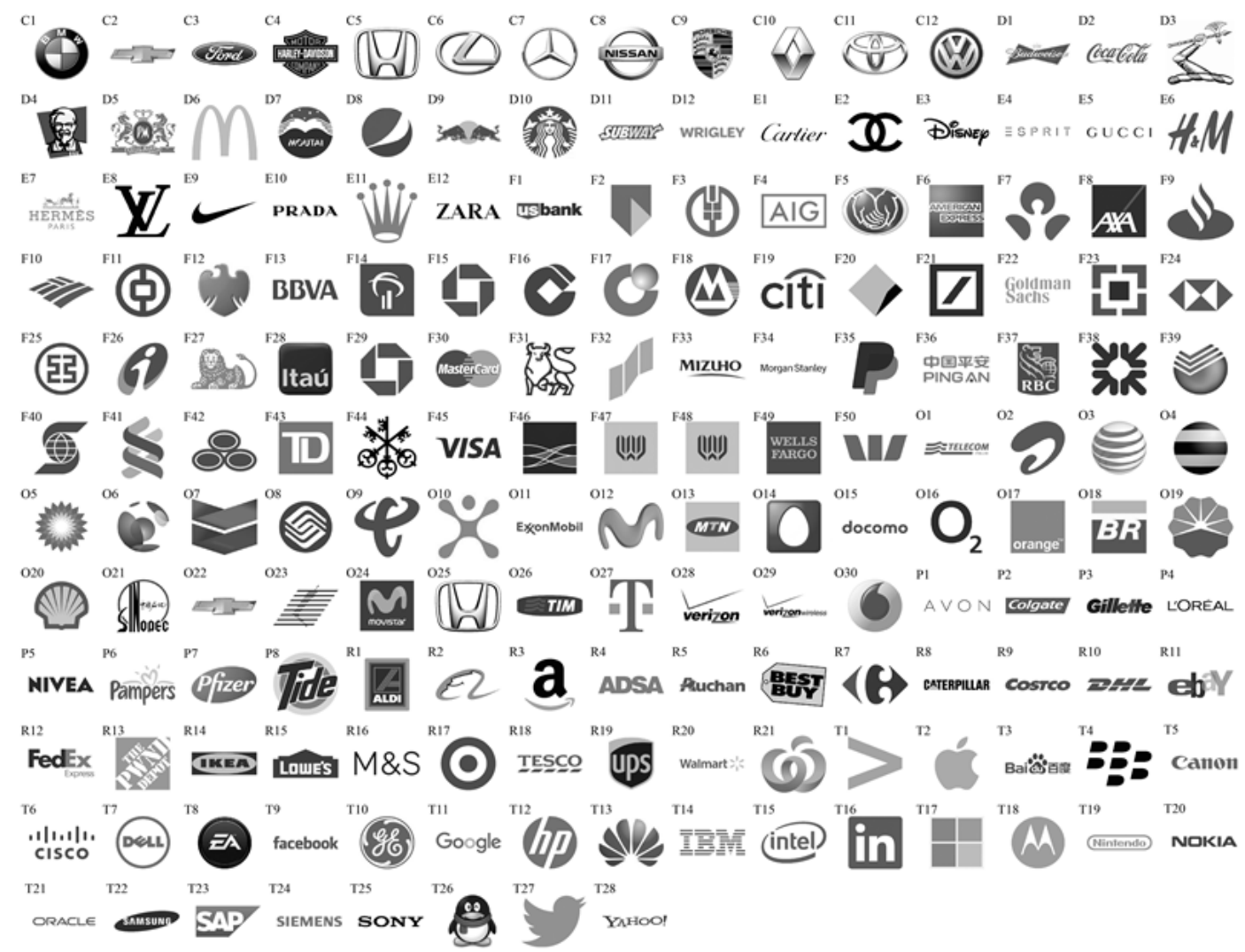

Figure-2. Two-dimensional trademarks of global top one hundred brands.

\subsection{Tools}

There were three common principles for brand judgement in this study for the planning of the test: (1) General Principal of awareness; (2) Overall observation principal; (3) Isolated comparing principal. Firstly, the researchers made the flash cards and each of them is $8 \mathrm{~cm} \mathrm{x} 8 \mathrm{~cm}$. Most the trademarks of global famous brands are color, the flash cards were in color to avoid losing the true to original.

\subsection{Statistical}

The number of samples of global top one hundred brands had reached 173. If they were compared in pairs, then over ten thousand times of similar judgement were involved. Since the brand competitors are always the enterprises of the same industry, this study classified the 173 samples into eight major industries. They are: (1) Cars; (2) Drinks \& Food; (3) Entertainment, Apparel, \& Luxury; (4) Financial; (5) Oil, Gas, \& Telecom; (6) Personal Care \& Medical; (7) Retail \& Logistics; (8) Technology. Then the figure similarity judgement of each industry was implemented. This study applied Multidimensional Scaling (MDS) to establish the Brand Positioning Map (BPM) of the eight major industries.

\section{RESULT}

This study applied Multidimensional Scaling (MDS) to implement similarity judgement. The quantitative Multidimensional Scaling (MDS) engages with quantitative data, such as ratio scale. This study got the brand figure similarity of the eight major industries from the participants, and the data matrix of similarity would further be established. Finally, the two-dimensional Brand Positioning Map (BPM) would be formed. Although the Stress of two-dimensional distribution 
chart will relatively be higher, it can better explain the historic trend of brands. The Stress and RSQ of eight major industries are shown in Table 1.

Table-1. Stress and RSQ of eight major industries

\begin{tabular}{l|l|l|l|l}
\hline Code & Industry & Industry code & Stress & RSQ \\
\hline 1 & Cars & C & 0.1549 & 0.9318 \\
\hline 2 & Drinks \& Food & D & 0.2831 & 0.5963 \\
\hline 3 & Entertainment, Apparel, \& Luxury & E & 0.2791 & 0.6692 \\
\hline 4 & Financial & F & 0.3170 & 0.6693 \\
\hline 5 & Oil, Gas, \& Telecom & $\mathrm{O}$ & 0.3121 & 0.6304 \\
\hline 6 & Personal Care \& Medical & P & 0.2413 & 0.7181 \\
\hline 7 & Retail \& Logistics & R & 0.3030 & 0.6232 \\
\hline 8 & Technology & T & 0.3584 & 0.4107 \\
\hline
\end{tabular}

This study applied Multidimensional scaling (MDS) to establish the brands on two-dimensional plane according to the brand distinctiveness of the eight major industries. From Figure 3 to Figure 10, the Brand Positioning Map (BPM) of the following eight major industries is shown: (1) Cars; (2) Drinks \& Food; (3) Entertainment, Apparel, \& Luxury; (4) Financial; (5) Oil, Gas, \& Telecom; (6) Personal Care \& Medical; (7) Retail \& Logistics; (8) Technology.

\subsection{Brand Positioning Map of Cars}

In $2006-2015$, there were 12 brands from Cars industry (Code C) entering the global top one hundred brand. There were 3-4 competitive groups. According to the yearly trend, there was maximum number of brand competitors (12 enterprises) in 2006. In 2015, the brand competitors were reduced to 6 enterprises. This shows that the Cars industry weeded the small enterprises out gradually. Please refer to Figure 3.

\section{C: Cars}
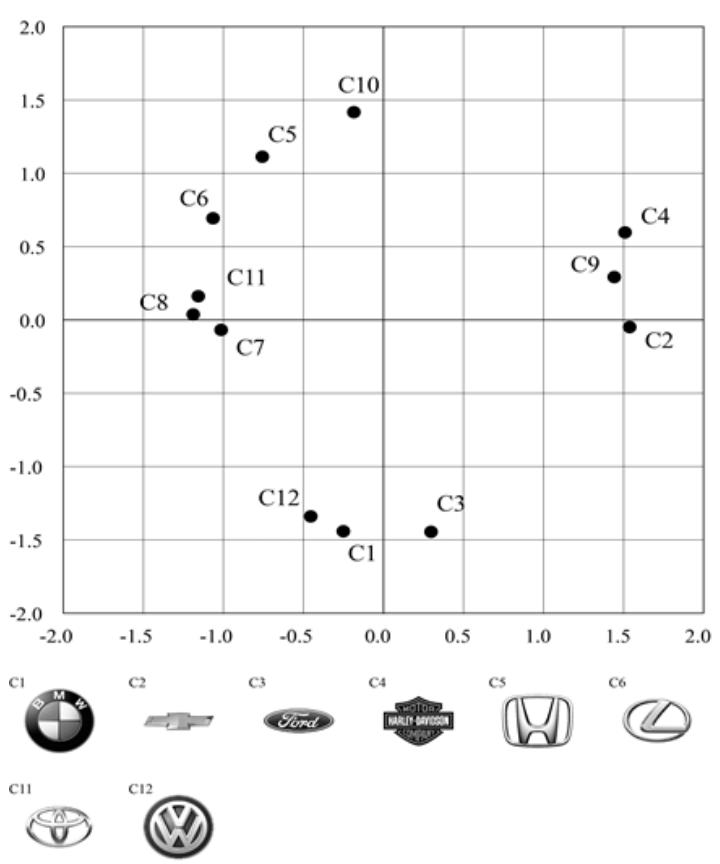

2006

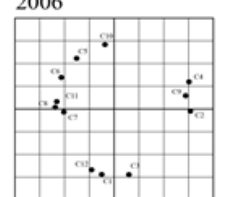

2009

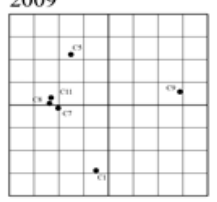

2012

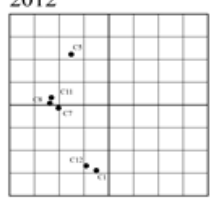

C3
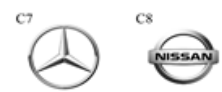

2007

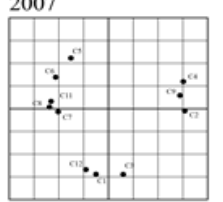

2010

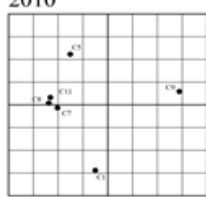

2013
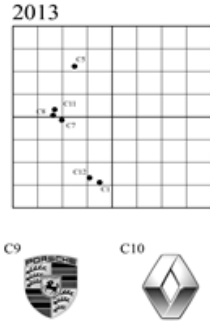

2008

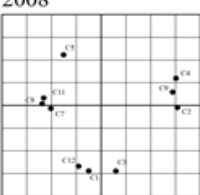

2011

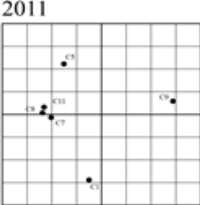

2014

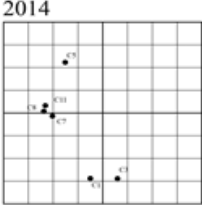

2015

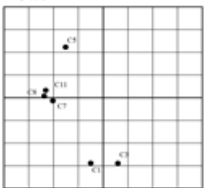

Figure-3. 2006-2015 Brand positioning map of cars industrial. 


\subsection{Brand Positioning Map of Drinks $\Xi^{\circ}$ Food}

In 2006 - 2015, there were 12 brands from Drinks \& Food industry (Code D) entering the global top one hundred brand. There were 2-3 competitive groups. According to the yearly trend, the brand competitors from 2006 to 2015 were almost the same. This shows that the competitors of Drinks \& Food were very stable. Please refer to Figure 4.

\section{D: Drinks \& Food}
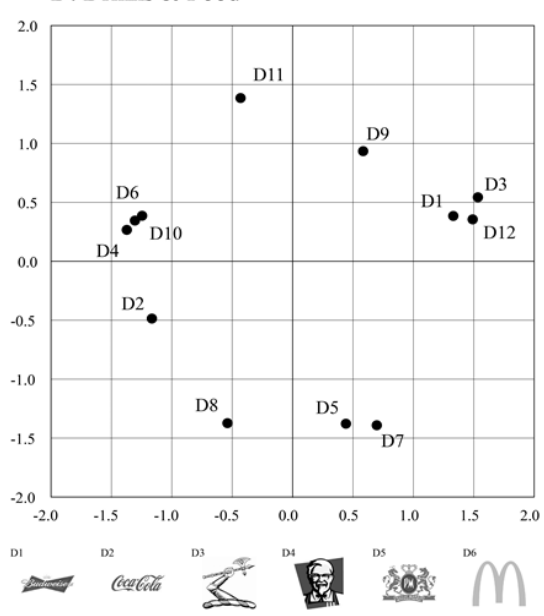

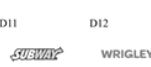
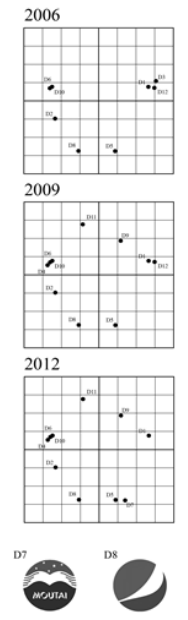

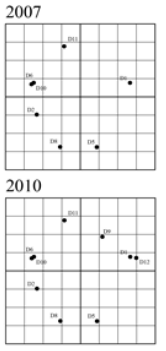

2013
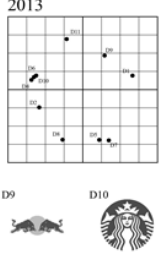

Figure-4. 2006-2015 Brand positioning map of drinks \& food industrial.
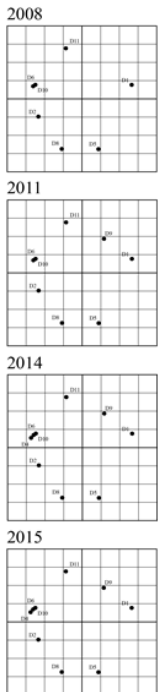

3.3. Brand Positioning Map of Entertainment, Apparel, \& Luxury

In 2006 - 2015, there were 12 brands from Entertainment, Apparel, \& Luxury industry (Code E) entering the global top one hundred brand. There were $2-5$ competitive groups. According to the yearly trend, there was maximum number of brand competitors (11 enterprises) in 2006. In 2015, the brand competitors were reduced to 7 enterprises. This shows that the Entertainment, Apparel, \& Luxury industry weeded the small enterprises out gradually. Please refer to Figure 5.

E: Entertainment, Apparel, \& Luxury

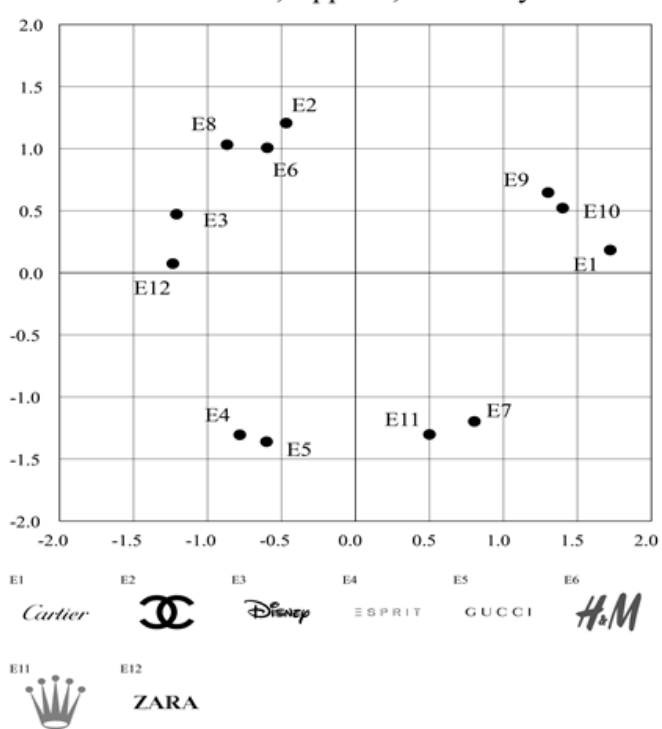

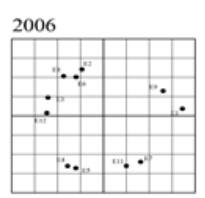
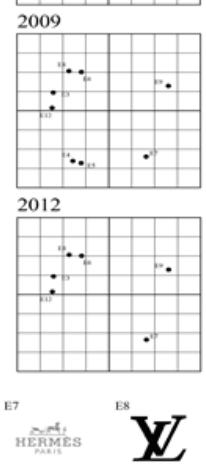
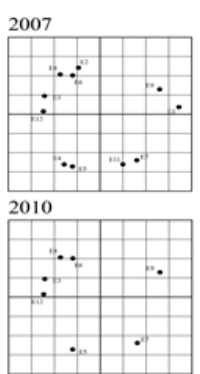

2013
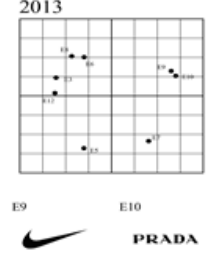

E10
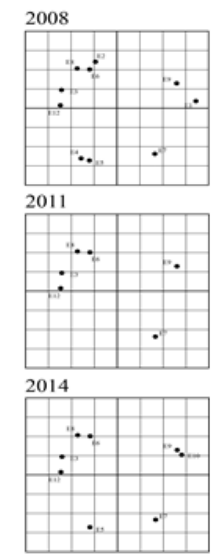

2015

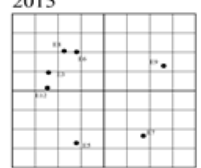

Figure-5. 2006-2015 Brand positioning map of entertainment, apparel, \& luxury industrial. 


\subsection{Brand Positioning Map of Financial}

In $2006-2015$, there were 50 brands from Financial industry (Code F) entering the global top one hundred brand. There were 3-4 major competitive groups. According to the yearly trend, the brand competitors from 2006 to 2015 were even and there were maximum number of brands among the eight major industries. This shows that Financial industry relies on brand competition. In the future, the competitive stress of this industry will also be the greatest. Please refer to Figure 6 .
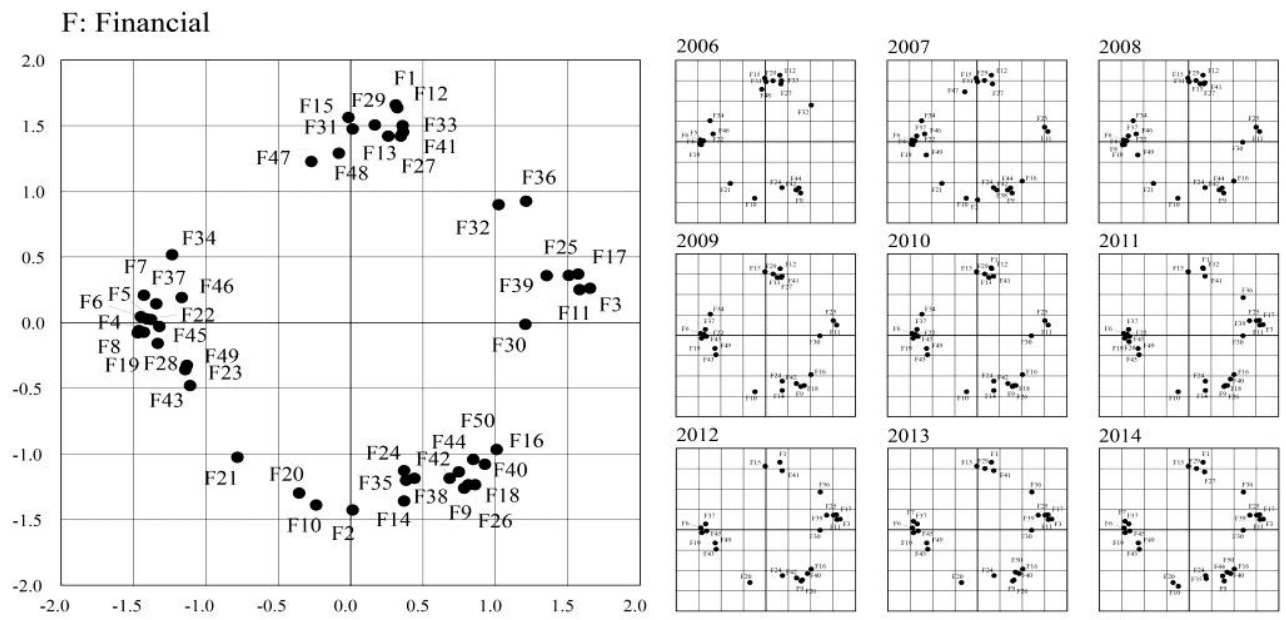

F

II 1

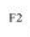

(I) $\quad$ AIG
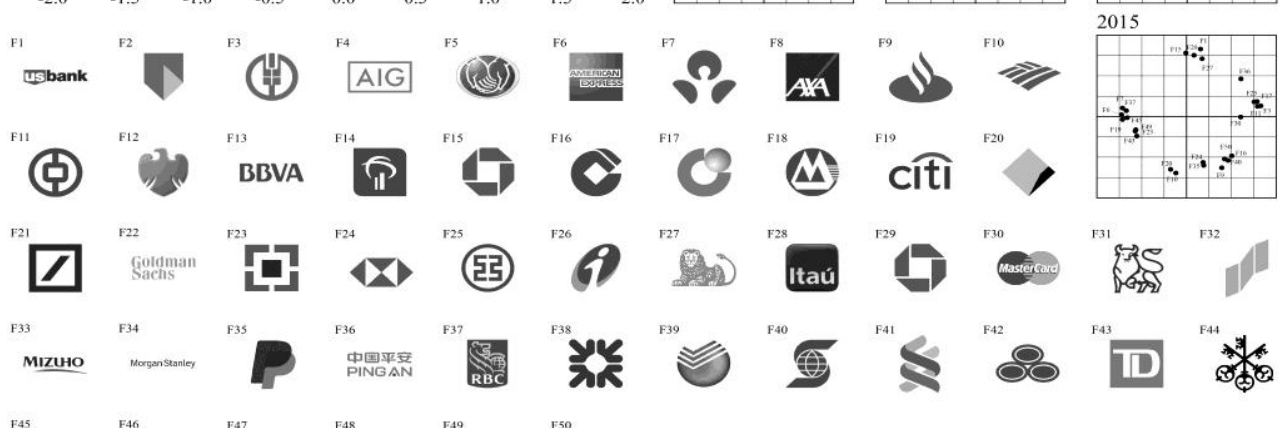

$\mathrm{F} 32$

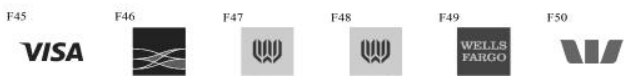

Figure-6. 2006-2015 Brand positioning map of financial industrial.

\subsection{Brand Positioning Map of Oil, Gas, \& Telecom}

In 2006 - 2015, there were 30 brands from Oil, Gas, \& Telecom industry (Code O) entering the global top one hundred brand. The distribution of brands was not obvious. Except sample O19 and O20 were relatively overlapped, the brand distinctiveness of this industry was relatively obvious. According to the yearly trend, there were fewer brand competitors (10 enterprises). In 2012, the brand competitors were increased to 21 enterprises. This shows that this industry will become the major industry in the future. The competitive stress of this industry will also be increased gradually. Please refer to Figure 7. 
O: Oil, Gas, \& Telecom

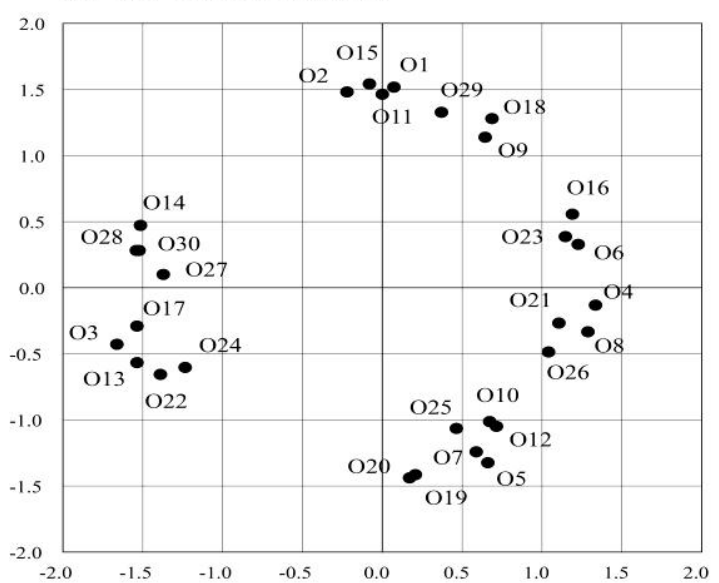$$
\text { @iruce }
$$

011

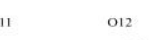

012
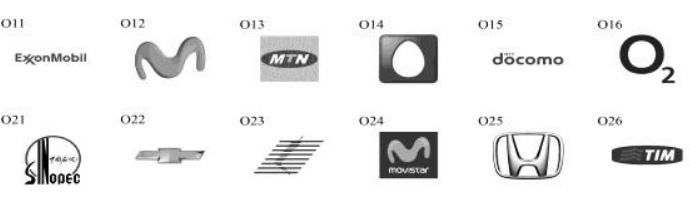

2006
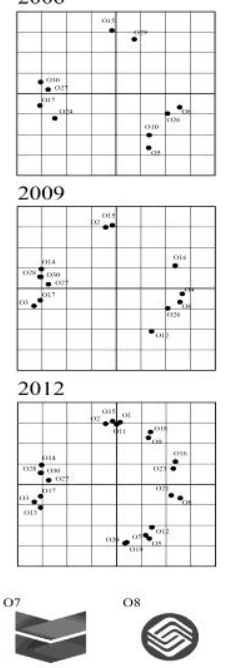
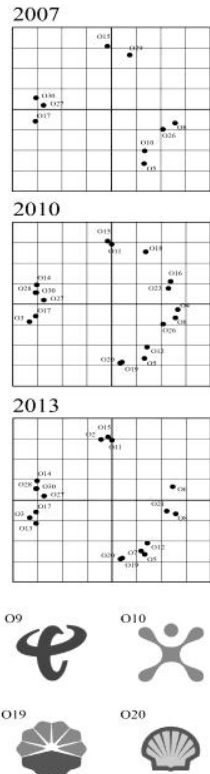
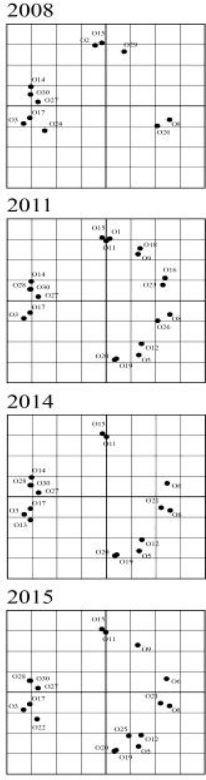

orange $\mathbf{E Z \mathbf { R }}$

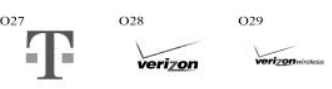

c

Figure-7. 2006-2015 Brand positioning map of oil, gas, \& telecom industrial.

\subsection{Brand Positioning Map of Personal Care \& Medical}

In $2006-2015$, there were 8 brands from Personal Care \& Medical industry (Code P) entering the global top one hundred brand. There were 2-3 competitive groups. According to the yearly trend, half of the brand competitors from 2006 to 2015 were different. This shows that the competition of this industry was violent during the past ten years. Please refer to Figure 8.

P: Personal Care \& Medical

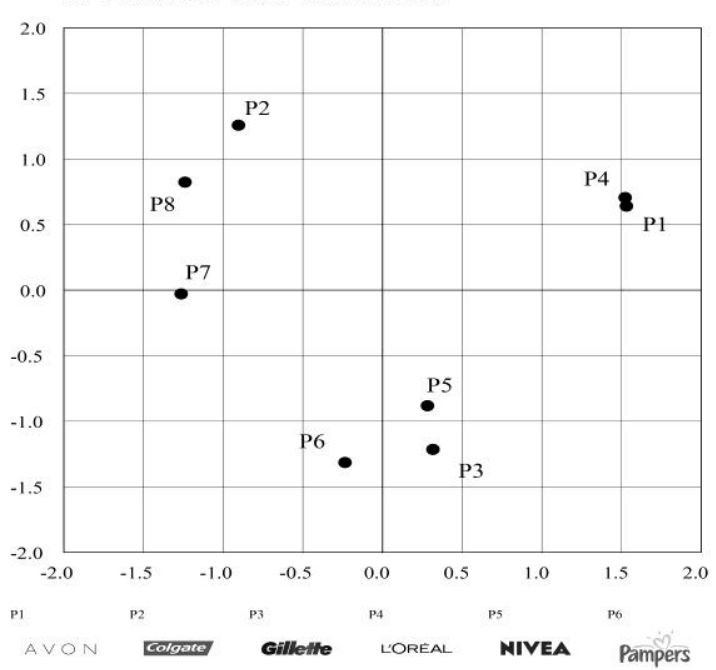

2006

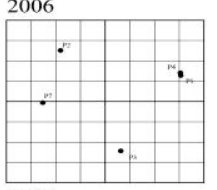

2009
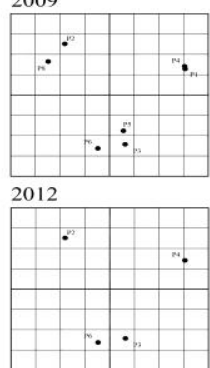

Pfize
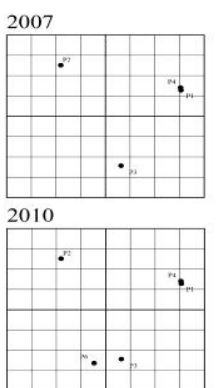

2013

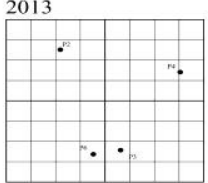

Fide

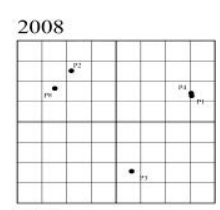

2011

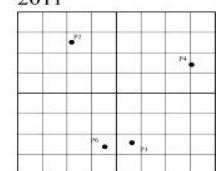

2014

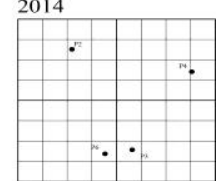

2015

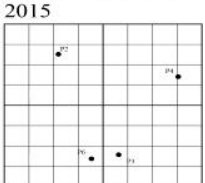

Figure-8. 2006-2015 Brand positioning map of personal care \& medical industrial 3.7. Brand positioning map of retail \& logistics 
In 2006 - 2015, there were 21 brands from Retail \& Logistics industry (Code R) entering the global top one hundred brand. Except sample R17 and R21 were relatively overlapped, the brand distinctiveness of this industry was relatively obvious. According to the yearly trend, the brand competitors from 2006 to 2015 were even. This shows that the brand distinctiveness and positioning is very clear. Please refer to Figure 9.

R: Retail \& Logistics

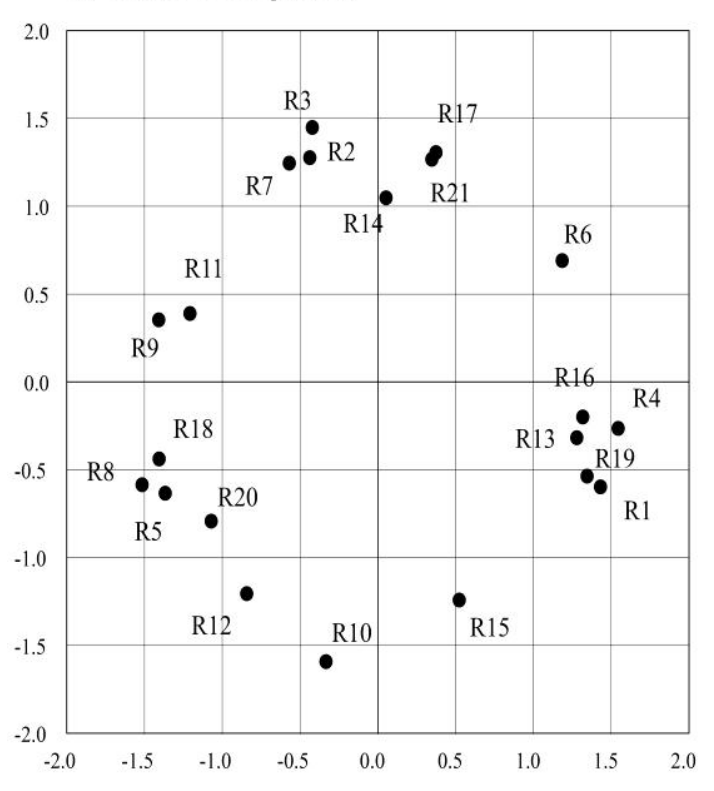

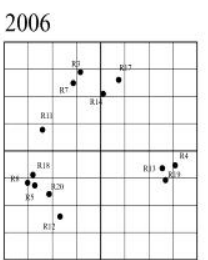

2009

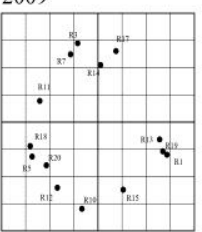

2012

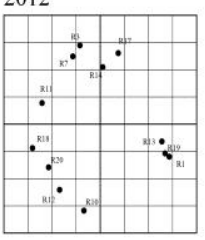

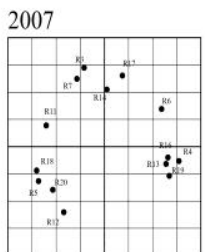

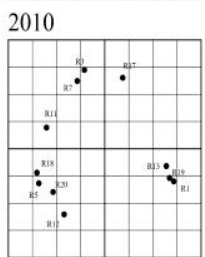

2013

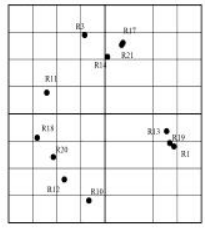

R9 $\quad$ R10

2)플
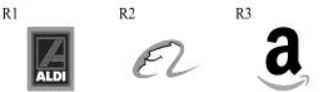

R11 R12

ebly Fed $x$

R13

ADSA Ruchan

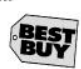

R7

R14 R15

R16

IKEA

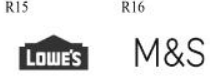

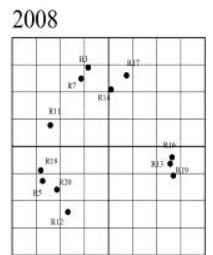

2011

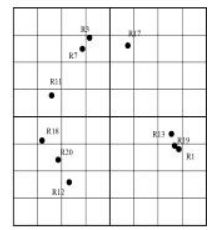

2014

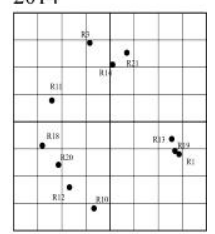

2015

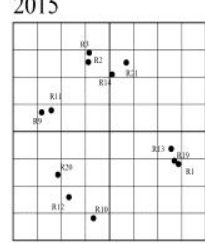

R21

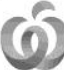

Figure-9. 2006-2015 Brand positioning map of retail \& logistics industrial.

\subsection{Brand Positioning Map of Technology}

In 2006 - 2015, there were 28 brands from Technology industry (Code R) entering the global top one hundred brand. There were 3 major competitive groups. According to the yearly trend, the brand competitors from 2006 to 2015 were even and many brands were involved. This shows that the competition of that industry was violent in the past ten years. Please refer to Figure 10. 


\section{T: Technology}

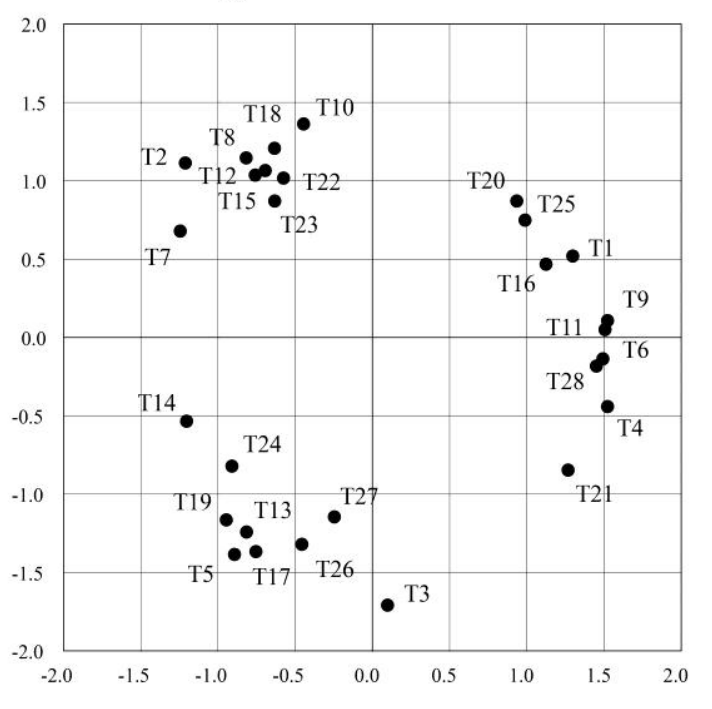

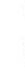$$
\text { T11 }
$$$$
\text { T11 }
$$

Google

T21

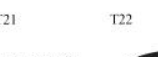

$\mathrm{T} 2$

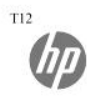

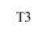

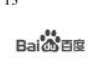

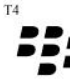

$\mathrm{TI} 3$

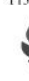

T14

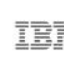

T15

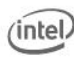

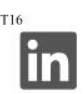

T24

SIEMEN
SONY
2006

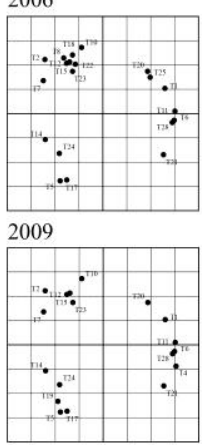

2012

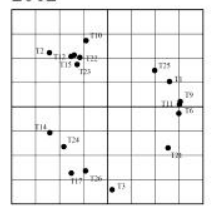

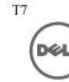

T17
2007

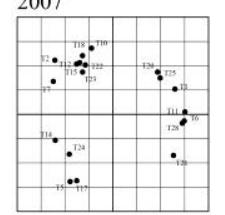

2010

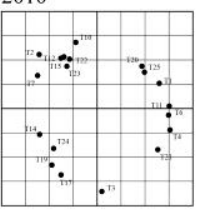

2013

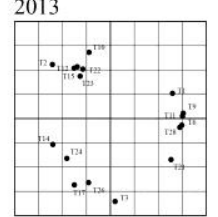

T9

T10

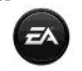

facebook

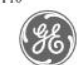

T18

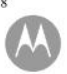

T19 T20

Niintendo NOKIA

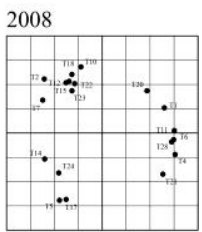

2011
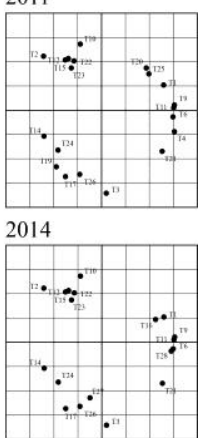

2015

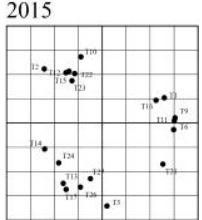

\section{T23}

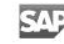

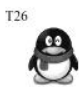

"

$\mathrm{T} 28$

YAHOO!

Figure-10. 2006-2015 Brand positioning map of technology industrial.

\section{DISCUSSION AND CONCLUSION}

There were 60 general consumers participating in this study. Among them, there were 21 male $(35 \%)$ and 39 female (65\%). On average, the participants had middle level above of familiarity to the brands of eight major industries (3.14 from Likert Scale). This study applied Multidimensional scaling (MDS) to implement similarity judgement of flash cards in order to get the brand figure similarity of the eight major industries from the participants. Researchers also established the data matrix of similarity and formed the two-dimensional Brand Positioning Map (BPM). The twodimensional distribution chart provides better visual effect to the executives of the enterprises on brand strategy.

The researchers further summarized the brand competitive stress of the eight major industries in the past years (2006-2015). Brand competitive stress means the number of brands in specific industry in that year. If there are more brands in that industry, it is predicated that the brand competitive stress would be bigger (maximum value of stress is 1 , and minimum value is 0 ). Take Drinks \& Foods industry (code D) as example, there were 12 brands entering global top one hundred in 2006-2015. In 2006, there were 8 brands in industry D. Therefore, the brand competitive stress of industry $\mathrm{D}$ in 2006 was $8 / 12=0.67$ (which belongs to middle level of competitive stress). According to this data, this study found the average annual competitive stress and average industrial competitive stress as shown in Table 2. 
Table-2. Brand competitive stress of 8 major industries.

\begin{tabular}{|c|c|c|c|c|c|c|c|c|c|c|}
\hline Year & Industrial code & $\mathbf{C}$ & D & $\mathbf{E}$ & $\mathbf{F}$ & $\mathbf{O}$ & $\mathbf{P}$ & $\mathbf{R}$ & $\mathbf{T}$ & $\begin{array}{l}\text { Average annual } \\
\text { competitive stress }\end{array}$ \\
\hline \multirow{2}{*}{2006} & Number of brands & 12 & 8 & 11 & 21 & 10 & 5 & 13 & 20 & \multirow{2}{*}{0.66} \\
\hline & Competitive stress & 1.00 & 0.67 & 0.92 & 0.42 & 0.33 & 0.63 & 0.62 & 0.71 & \\
\hline \multirow{2}{*}{2007} & Number of brands & 11 & 7 & 11 & 25 & 9 & 4 & 14 & 19 & \multirow{2}{*}{0.63} \\
\hline & Competitive stress & 0.92 & 0.58 & 0.92 & 0.50 & 0.30 & 0.50 & 0.67 & 0.68 & \\
\hline \multirow{2}{*}{2008} & Number of brands & 10 & 7 & 10 & 26 & 11 & 5 & 12 & 19 & \multirow{2}{*}{0.63} \\
\hline & Competitive stress & 0.83 & 0.58 & 0.83 & 0.52 & 0.37 & 0.63 & 0.57 & 0.68 & \\
\hline \multirow{2}{*}{2009} & Number of brands & 6 & 10 & 8 & 24 & 13 & 7 & 14 & 18 & \multirow{2}{*}{0.64} \\
\hline & Competitive stress & 0.50 & 0.83 & 0.67 & 0.48 & 0.43 & 0.88 & 0.67 & 0.64 & \\
\hline \multirow{2}{*}{2010} & Number of brands & 6 & 9 & 7 & 25 & 18 & 5 & 11 & 19 & \multirow{2}{*}{0.60} \\
\hline & Competitive stress & 0.50 & 0.75 & 0.58 & 0.50 & 0.60 & 0.63 & 0.52 & 0.68 & \\
\hline \multirow{2}{*}{2011} & Number of brands & 6 & 8 & 6 & 27 & 19 & 4 & 10 & 20 & \multirow{2}{*}{0.57} \\
\hline & Competitive stress & 0.50 & 0.67 & 0.50 & 0.54 & 0.63 & 0.50 & 0.48 & 0.71 & \\
\hline \multirow{2}{*}{2012} & Number of brands & 6 & 10 & 6 & 23 & 22 & 4 & 12 & 17 & \multirow{2}{*}{0.59} \\
\hline & Competitive stress & 0.50 & 0.83 & 0.50 & 0.46 & 0.73 & 0.50 & 0.57 & 0.61 & \\
\hline \multirow{2}{*}{2013} & Number of brands & 6 & 10 & 8 & 25 & 18 & 4 & 12 & 17 & \multirow{2}{*}{0.60} \\
\hline & Competitive stress & 0.50 & 0.83 & 0.67 & 0.50 & 0.60 & 0.50 & 0.57 & 0.61 & \\
\hline \multirow{2}{*}{2014} & Number of brands & 6 & 9 & 8 & 27 & 16 & 4 & 11 & 19 & \multirow{2}{*}{0.59} \\
\hline & Competitive stress & 0.50 & 0.75 & 0.67 & 0.54 & 0.53 & 0.50 & 0.52 & 0.68 & \\
\hline \multirow{2}{*}{2015} & Number of brands & 6 & 9 & 7 & 26 & 17 & 4 & 12 & 19 & \multirow{2}{*}{0.58} \\
\hline & Competitive stress & 0.50 & 0.75 & 0.58 & 0.52 & 0.57 & 0.50 & 0.57 & 0.68 & \\
\hline \multirow[t]{2}{*}{$\begin{array}{l}2006- \\
2015\end{array}$} & $\begin{array}{l}\text { Total number of } \\
\text { enterprises }\end{array}$ & 12 & 12 & 12 & 50 & 30 & 8 & 21 & 28 & Sum: 173 \\
\hline & $\begin{array}{l}\text { Average industrial } \\
\text { competitive stress }\end{array}$ & 0.63 & 0.73 & 0.68 & 0.50 & 0.51 & 0.58 & 0.58 & 0.67 & Ave: 0.61 \\
\hline
\end{tabular}

From the annual trend of eight major industries, the brand competitive stress of each industry could be observed. Among them, the three industries with the highest competitive stress were D, $\mathrm{E}$, and $\mathrm{T}$ respectively. It was shown that the number of competitors of industry $\mathrm{D}, \mathrm{E}$, and $\mathrm{T}$ were stable and well matched in strength. In addition, the industries with lower competitive stress were $\mathrm{F}$ and $\mathrm{O}$. It was shown that the industry $\mathrm{F}$ and $\mathrm{O}$ weeded the small enterprises out gradually.

From the overall observation, there were 50 enterprises from Financial industry entering the global top one hundred brands, for which it occupied $29 \%$ of all brands (173 enterprises). This showed that brand was the major competition for Financial industry. From the brand distinctiveness, most of the industries had excellent brand distinctiveness except the brands of Financial industry, which were relatively highly overlapped. This showed that the consumers had clear impression of global brands, which had high distinctiveness.

Through the sample distribution of global top one hundred brands of this study, it is expected to understand the developing trend and brand positioning of global brands, and it can become the reference to enterprises planning the brand image. The enterprises can apply this analysis to establish their own Brand Positioning Map (BPM) in the future in order to understand the trend and positioning of the own brands in the industry.

Funding: This study received no specific financial support.

Competing Interests: The authors declare that they have no competing interests.

Acknowledgement: All authors contributed equally to the conception and design of the study. 


\section{REFERENCES}

Aarstad, J., Ness, H., \& Haugland, S. A. (2015). Network position and tourism firms' co-branding practice. Journal of Business Research, 68, 1667-1677. Arvidsson, A. (2006). Brand value. Journal of Brand Management, 13, 188-192.

BrandZ (2016). Global Top 100. http://wppbaz.com/ContentCollection/23.

Chen, A., \& Chen, R. (2007). A seven-track protection mechanism for design knowledge. Scientific Inquiry, 8, 195-206.

Chen, A., \& Liang, C. (2012). Using trademark map for brand image positioning. Journal of Computer Vision and Image Processing, 2, 11-16.

Chen, A., \& Wang, M. H. (2015). Brand positioning map: a strategy tool for trademark design. Journal of Management and Strategy, 6, 36-44.

Copyright Act (2016). Laws \& regulations database of the R.O.C. http://law.moj.gov.tw/Eng/LawClass/LawContent.aspx?pcode=J0070017.

Jeng, M. Y., \& Yeh, T. (2016). The effect of consumer values on the brand position of green restaurants by means-end chain and laddering interviews. Service Business, 10, 223-238.

Johan, G., \& Frans, M. (2011). The underlying dimensions of brand orientation and its impact on financial performance. Journal of Brand Management, 18, 394-410.

Liu, Y. T. (1995). Some phenomena of seeing shapes in design. Design Studies, 16, 367-385.

Lubiano, M. A., de Saa, S. D., Montenegro, M., Sinova, B., \& Gil, M. A. (2016). Descriptive analysis of responses to items in questionnaires. Why not using a fuzzy rating scale?. Information Sciences, 360, 131-148.

Mealem, Y., Yacobi, Y., \& Yaniv, G. (2010). Trademark infringement and optimal monitoring policy. Journal of Economics and Business, 62, 116-128.

Parker, B. T. (2009). A comparison of brand personality and branduser-imagery Congruence. Journal of Consumer Marketing, 26, 175-184.

Patent Act (2016). Laws \& regulations database of the R.O.C. http://law.moj.gov.tw/Eng/LawClass/LawContent.aspx?pcode=J0070007.

Thiripurasundari, U., \& Natarajan, P. (2011). An empirical study on determinant and measurement of brand equity in Indian car industry. Asia Pacific Journal of Research in Business Management, 2, 158-169.

Trademark Act (2016). Laws \& regulations database of the R.O.C. http://law.moj.gov.tw/Eng/LawClass/LawContent.aspx?pcode=J0070001.

Views and opinions expressed in this article are the views and opinions of the author(s), Journal of Asian Business Strategy shall not be responsible or answerable for any loss, damage or liability etc. caused in relation to/arising out of the use of the content. 